Deep Sea Research Part II: Topical Studies in Oceanography July 2018, Volume 153 Pages 1-3

https://doi.org/10.1016/i.dsr2.2018.09.011

https://archimer.ifremer.fr/doc/00463/57473/

\title{
Fluids and processes at the seismically active fault zone in the Sea of Marmara
}

\author{
Ruffine Livio ${ }^{1,}$, Çağatay M. Namık ${ }^{2}$, Géli Louis ${ }^{3}$
}

${ }^{1}$ IFREMER, Département Ressources physiques et Ecosystèmes de fond de Mer (REM), Unité des Géosciences Marines, 29280 Plouzané, France

${ }^{2}$ Istanbul Technical University, Faculty of Mines, Dept of Geology Engineering, TR-34469 Istanbul, Turkey

${ }^{3}$ IFREMER, Département Ressources physiques et Ecosystèmes de fond de Mer (REM), Unité des Géosciences Marines, 29280 Plouzané, France

* Corresponding author : Livio Ruffine, email address : livio.ruffine@ifremer.fr 


\section{Introduction}

Understanding the relationships between fluid origin and migration, fault dynamics and the seismicity of the Marmara Region involves answering key questions. Amongst them, questions on earthquake cycles, seismic event occurrences, gas emission distribution at locked or creeping fault segments, as well as the fate of fluids in both the sedimentary and water columns systematically arise. The occurrence of cold seeps at the seafloor is a clear visual expression of shallow fluid migration, which are widely observed in the Sea of Marmara (SoM). Cold seeps are mostly located along the North Anatolian Fault (NAF) system and inherited faults (Zitter et al., 2008). They were first detected during the $R / V$ Meteor Cruise Leg M44/1 in February 1999 (Halbach et al., 2002) but visually observed for the first time during the Marmarascarps cruise (2002) using the ROV (Remotely Operated Vehicle)-Victor 6000. However, the Marmarascarps expedition was devoted to the investigation of the submarine morphology of the SoM, without specific attention to fluid seepage (Armijo et al., 2005). Since this expedition, the idea of possible links between fluid expulsion from the seafloor at cold seeps and the functioning of the Marmara Fault System became apparent (Zitter et al., 2008), and two fluid-oriented scientific cruises, Marnaut in 2007 and MarmEsonet in 2009, were consequently undertaken.

The Marnaut expedition, with the manned submersible Nautile, was conducted in May-June 2007 onboard the $R / V$ Atalante (http://dx.doi.org/10.17600/7010070). It was dedicated to the mapping of gas emissions, and the sampling and analysis of fluids and carbonate crusts along the submerged NAF system. The main objective was to study the origin of the fluids and the possible relationships between fluid emissions and fault activity (Bourry et al., 2009; Burnard et al., 2012; Dupré et al., 2012; Dupré et al., 2015; Géli et al., 2008). Three active venting sites were sampled at which the collected gases were significantly different in their composition and origin. The gases were of thermogenic origin on the Western and Central highs and genetically related to the Thrace hydrocarbon Basin, whereas microbial gases were predominant in the easternmost Çınarcık Basin (Bourry et al., 2009; Ruffine et al., 2012). Gas hydrates were discovered and recovered for the first time on the Western High, the analysis of which revealed s-II structure with a high content of heavy hydrocarbons. The recovered samples were the most propane-enriched hydrates ever collected (Bourry et al., 2009; Ruffine et al., 2012). The pore fluids were very diverse and complex in composition, reflecting mixing of fluids from different sources (Ruffine et al., 2015; Tryon et al., 2010; Zitter et al., 2008) as well as variations with time (Tryon et al., 2012). Such fluid emissions favored the 
development of microbial chemosynthetic communities (Ritt et al., 2010); especially those involved in the anaerobic oxidation of methane (AOM) and other heavier hydrocarbons. The $\mathrm{AOM}$ at the cold seep sites was also associated with deposition of carbonate crusts (Crémière et al., 2013; Crémiere et al., 2012).

Two years later, the MarmEsonet (http://dx.doi.org/10.17600/9020040) cruise was conducted in November-December 2009 on board the $R / V$ Le Suroit. Given the multitude of gas seeps observed during the Marnaut-cruise dives, priority was given to (1) the mapping of gas plumes for the entire Sea of Marmara by both shipborne multibeam and AUV-driven acoustic surveys of the water column, and (2) the characterization of the plumbing system by 3D seismics. The main results of the cruise were fittingly summarized in Dupré et al. (2015) as: "Gas emissions are spatially controlled by a combination of factors, including fault and fracture networks in connection to the Main Marmara Fault system and inherited faults, the nature and thickness of sediments (e.g., occurrence of impermeable or gas-bearing sediments and landslides), and the connectivity between the seafloor and gas sources, particularly in relation to the Eocene Thrace Basin. The relationship between seepage and fault activity is not linear, as active faults do not necessarily conduct gas, and scarps corresponding to deactivated fault strands may continue to channel fluids. Within sedimentary basins, gas is not expelled at the seafloor unless faulting, deformation, or erosional processes affect the sediments. On topographic highs, gas flares occur along the main fault scarps but are also associated with sediment deformation." Thus, undoubtedly, the occurrence of seeps in the SoM is influenced by the dynamics of fault networks and geological processes affecting the sedimentary column. These factors control their inception, intensity and lifetime as well as the chemical composition of fluids via source mixing.

Based on the outcomes of these two cruises, the MarsiteCruise expedition (http://dx.doi.org/10.17600/14000500) was scheduled in November 2014. The main objective was to improve our understanding of the relationships between fault activity, fluid migration and seismicity in the Marmara region. This marine expedition was divided into three legs with three scientific aims. The first was devoted to the deployment of submarine instrumentation to collect long period series of geodetic and geophysical data to determine correlations between fault motion, intermittent fluid discharge and micro-seismicity (Sakic et al., 2016). The second leg was dedicated to ROV-Victor 6000 dives to investigate the geochemical dynamics of selected cold-seep sites. The third leg allowed the recovery of long-gravity cores for dating some seismic reflector surfaces to establish chronostratigraphy for the last few thousand years and obtain fault slip rates. 
The present Special Issue, entitled "Fluids and processes at the seismically active fault zone in the Sea of Marmara", provides new insights into the aforementioned topics. The questions on the links between fluids, faults and seismicity in the SoM are debated in the 10 contributions composing this special issue. The first article summarizes the earthquake geological studies carried out since the Mw 7.4 and 7.3 1999 eastern Marmara earthquakes under collaborative studies between Italian and Turkish scientists (Gasperini et al., 2018). The main objectives were to map active faults and determine slip-rates, earthquake recurrence times, and possible relationships between fluid emissions and fault activity. The average slip-rates for the last $10 \mathrm{kyrs}$ were found to be $10 \mathrm{~mm} / \mathrm{yr}$ on the northern strand and $3-4 \mathrm{~mm} / \mathrm{yr}$ along the middle strand of the NAF (Gasperini et al., 2018). Submarine paleoseismological studies in the Gulf of İzmit suggested an average recurrence time of 300 years over the late Holocene. The work of Grall et al. (2018) deals with the gas distribution in relation to geological characteristics of the sea such as geomorphology and stratigraphy of the sedimentary column. This study demonstrates that gas seeps appear to be localized within 1-2 km of the active fault zones, fault intersections between subsidiary faults and main faults, along basin edges that cross updip gas migration pathways and topographic highs, where the fault appears to be creeping. On the contrary, the seeps are rare along active fault segments crossing basin depocenters and the Central High segment which appears to be locked (Grall et al., 2018).

MarsiteCruise provided the opportunity to develop a new strategy for gas-seep detection, and this is described in detail in the Special Issue (Ruffine et al., 2018b). Such a strategy allowed us to detect and sample 18 gas seeps. It has been shown that the gas bubbles emitted at the seafloor are mixtures of primary and secondary microbial gases with thermogenic and mantlederived gases with very asymmetric contribution of each source (Ruffine et al., 2018a). The sediments in the vicinity of the seeps host living benthic Foraminifera, and a study from samples collected on the Central High and the Çınarcık Basin show that Bolivina vadescens and Globobulimina affinis are the two dominant species at the study areas (Fontanier et al., 2018). Three articles (Akhoudas et al., 2018; Çağatay et al., 2018; Teichert et al., 2018) deal specifically with the texture, mineralogical and isotopic compositions and genesis of authigenic carbonate crusts associated with cold seeps in the SoM. These studies demonstrate the use of crusts as archives of past fluid activity and possibly of earthquake activity. The study by Çağatay et al. (2018) shows that the authigenic carbonates and black sulfidic sediments were formed by the AOM at or near the seafloor during less than $1 \mathrm{kyr}$ BP to 9.6 kyr BP, as a result of high methane flux, possibly associated with high seismic activity and gas hydrate destabilization due to global warming. Çağatay et al. (2018) also discuss the 
problems using authigenic carbonate crusts as archives of paleoseismic activity. However, the high-resolution multi-proxy study carried out by Teichert et al. (2018) provides a promising example of the use of authigenic carbonates as archives of past seismic activity. Iron has also been investigated as proxy for tracing the migration of fluids within the sedimentary column and their discharge at the seafloor (Yang et al., 2018). The presence of metastable ferromagnetic iron sulfide minerals on the Western High indicates a more reducing environment resulting from the degradation of heavy hydrocarbons and organic matter. The last article (Henry et al., 2018) links fluid emission and fault activity. It has been shown that most of the gas emissions are located within a distance shorter than $750 \mathrm{~m}$ from the faults, and irrespective of creeping or locked segments.

\section{Acknowledgements}

We thank the captain and his crew on-board the $R V$ Pourquoi pas? as well as the team of the ROV Victor-6000 crew for their technical support and advice. We also express our acknowledgements to all cruise participants and scientists who contributed to this project. Financial support was provided by the European programme «MARsite», under the call ENV.2012.6.4-2: "Long-term monitoring experiment in geologically active regions of Europe prone to natural hazards: the Supersite concept". This work was also supported by the "Laboratoire d'Excellence" LabexMER (ANR-10-LABX-19) through projects MicroGaMa and MISS Marmara, co-funded by a grant from the French government under the program "Investissements d'Avenir". 


\section{References}

Akhoudas, C., Chevalier, N., Blanc-Valleron, M.M., Klein, V., Mendez-Millan, M., Demange, J., Dalliah, S., Rommevaux, V., Boudouma, O., Pierre, C., Ruffine, L., 2018. Methane-derived stromatolitic carbonate crust from an active fluid seepage in the western basin of the Sea of Marmara: Mineralogical, isotopic and molecular geochemical characterization. Deep Sea Research Part II: Topical Studies in Oceanography.

Armijo, R., Pondard, N., Meyer, B., Ucarkus, G., de Lepinay, B.M., Malavieille, J., Dominguez, S., Gutscher, M.A., Schmidt, S., Beck, C., Cagatay, N., Cakir, Z., Imren, C., Eris, K., Natalin, B., Ozalaybey, S., Tolun, L., Lefevre, I., Seeber, L., Gasperini, L., Rangin, C., Emre, O., Sarikavak, K., 2005. Submarine fault scarps in the Sea of Marmara pull-apart (North Anatolian Fault): Implications for seismic hazard in Istanbul. Geochemistry Geophysics Geosystems 6.

Bourry, C., Chazallon, B., Charlou, J.L., Donval, J.P., Ruffine, L., Henry, P., Geli, L., Cagatay, M.N., Inan, S., Moreau, M., 2009. Free gas and gas hydrates from the Sea of Marmara, Turkey Chemical and structural characterization. Chemical Geology 264, 197-206.

Burnard, P., Bourlange, S., Henry, P., Geli, L., Tryon, M., Sengör, A., Özeren, M., Çagatay, M., 2012. Constraints on fluid origins and migration velocities along the Marmara Main Fault (Sea of Marmara, Turkey) using helium isotopes. Earth and Planetary Science Letters 341, 68-78.

Çağatay, M.N., Yıldız, G., Bayon, G., Ruffine, L., Henry, P., 2018. Seafloor authigenic carbonate crusts along the submerged part of the North Anatolian Fault in the Sea of Marmara: Mineralogy, geochemistry, textures and genesis. Deep Sea Research Part II: Topical Studies in Oceanography.

Crémière, A., Bayon, G., Ponzevera, E., Pierre, C., 2013. Paleo-environmental controls on cold seep carbonate authigenesis in the Sea of Marmara. Earth and Planetary Science Letters 376, 200-211.

Crémiere, A., Pierre, C., Blanc-Valleron, M.-M., Zitter, T., Cagatay, M.N., Henry, P., 2012. Methanederived authigenic carbonates along the North Anatolian fault system in the Sea of Marmara (Turkey). Deep-Sea Research Part I-Oceanographic Research Papers 66, 114-130.

Dupré, S., Scalabrin, C., Géli, L., Henry, P., Grall, C., Çagatay, N., Imren, C., Team, a.t.M.S.P., 2012. Widespread gas emissions in the Sea of Marmara, results from systematic ship-borne multibeam echosounder water column imageries. 11th International Conference of Gas in Marine Sediments Nice.

Dupré, S., Scalabrin, C., Grall, C., Augustin, J.-M., Henry, P., Sengor, A.M.C., Goeruer, N., Cagatay, M.N., Geli, L., 2015. Tectonic and sedimentary controls on widespread gas emissions in the Sea of Marmara: Results from systematic, shipborne multibeam echo sounder water column imaging. Journal of Geophysical Research-Solid Earth 120, 2891-2912.

Fontanier, C., Dissard, D., Ruffine, L., Mamo, B., Ponzevera, E., Pelleter, E., Baudin, F., Roubi, A., Chéron, S., Boissier, A., Gayet, N., Bermell-Fleury, S., Pitel, M., Guyader, V., Lesongeur, F., Savignac, F., 2018. Living (stained) deep-sea foraminifera from the Sea of Marmara: A preliminary study. Deep Sea Research Part II: Topical Studies in Oceanography.

Gasperini, L., Polonia, A., Çağatay, M.N., 2018. Fluid flow, deformation rates and the submarine record of major earthquakes in the Sea of Marmara, along the North-Anatolian Fault system. Deep Sea Research Part II: Topical Studies in Oceanography.

Géli, L., Henry, P., Zitter, T., Dupré, S., Tryon, M., Çagatay, M., de Lépinay, B., Le Pichon, X., engör, A., Görür, N., 2008. Gas emissions and active tectonics within the submerged section of the North Anatolian Fault zone in the Sea of Marmara. Earth and Planetary Science Letters 274, 34-39.

Grall, C., Henry, P., Dupré, S., Géli, L., Scalabrin, C., Zitter, T.A.C., Sengor, A.M.C., Namik Cagatay, M., Cifci, G., 2018. Upward migration of gas in an active tectonic basin: An example from the sea of Marmara. Deep Sea Research Part II: Topical Studies in Oceanography.

Halbach, P., Kuşçu, I., Inthorn, M., Kuhn, T., Pekdeğer, A., Seifert, R., 2002. Methane in sediments of the deep Marmara Sea and its relation to local tectonic structures, Integration of Earth Science Research on the Turkish and Greek 1999 Earthquakes. Springer, pp. 71-85. 
Henry, P., Grall, C., Kende, J., Viseur, S., Özeren, M.S., Şengör, A.M.C., Dupré, S., Saclabrin, C., Géli, L., 2018. A statistical approach to relationships between fluid emissions and faults: The Sea of Marmara case. Deep Sea Research Part II: Topical Studies in Oceanography.

Ritt, B., Sarrazin, J., Caprais, J.-C., Noël, P., Gauthier, O., Pierre, C., Henry, P., Desbruyeres, D., 2010. First insights into the structure and environmental setting of cold-seep communities in the Marmara Sea. Deep Sea Research Part I: Oceanographic Research Papers 57, 1120-1136.

Ruffine, L., Donval, J.-P., Croguennec, C., Burnard, P., Lu, H., Germain, Y., Legoix, L.N., Bignon, L., Çağatay, M.N., Marty, B., Madre, D., Pitel-Roudaut, M., Henry, P., Géli, L., 2018a. Multiple gas reservoirs are responsible for the gas emissions along the Marmara fault network. Deep Sea Research Part II: Topical Studies in Oceanography.

Ruffine, L., Fandino, O., Etoubleau, J., Chéron, S., Donval, J.P., Germain, Y., Ponzevera, E., Guyader, V., Dennielou, B., Etiope, G., Gasperini, L., Bortoluzzi, G., Henry, P., Grall, C., Çagatay, M.N., Charlou, J.L., Géli, L., 2012. Geochemical dynamics of the natural-gas hydrate system in the Sea of Marmara, offshore Turkey. Advances in Natural Gas Technology ISBN 978-953-51-0507-7, pp. 29-56.

Ruffine, L., Germain, Y., Polonia, A., de Prunele, A., Croguennec, C., Donval, J.-P., Pitel-Roudaut, M., Ponzevera, E., Caprais, J.-C., Brandily, C., Grall, C., Bollinger, C., Geli, L., Gasperini, L., 2015. Pore water geochemistry at two seismogenic areas in the Sea of Marmara. Geochemistry Geophysics Geosystems 16, 2038-2057.

Ruffine, L., Ondreas, H., Blanc-Valleron, M.-M., Teichert, B.M.A., Scalabrin, C., Rinnert, E., Birot, D., Croguennec, C., Ponzevera, E., Pierre, C., Donval, J.-P., Alix, A.-S., Germain, Y., Bignon, L., Etoubleau, J., Caprais, J.-C., Knoery, J., Lesongeur, F., Thomas, B., Roubi, A., Legoix, L.N., Burnard, P., Chevalier, N., Lu, H., Dupré, S., Fontanier, C., Dissard, D., Olgun, N., Yang, H., Strauss, H., Özaksoy, V., Perchoc, J., Podeur, C., Tarditi, C., Özbeki, E., Guyader, V., Marty, B., Madre, D., Pitel-Roudaut, M., Grall, C., Embriaco, D., Polonia, A., Gasperini, L., Çağatay, M.N., Henry, P., Géli, L., 2018b. Multidisciplinary investigation on cold seeps with vigorous gas emissions in the Sea of Marmara (MarsiteCruise): Strategy for site detection and sampling and first scientific outcome. Deep Sea Research Part II: Topical Studies in Oceanography.

Sakic, P., Piete, H., Ballu, V., Royer, J.Y., Kopp, H., Lange, D., Petersen, F., Ouml;zeren, M.S., Ergintav, S., Geli, L., Henry, P., Deschamps, A., 2016. No significant steady state surface creep along the North Anatolian Fault offshore Istanbul: Results of 6months of seafloor acoustic ranging. Geophysical Research Letters 43, 6817-6825.

Teichert, B.M.A., Chevalier, N., Gussone, N., Bayon, G., Ponzevera, E., Ruffine, L., Strauss, H., 2018. Sulfate-dependent anaerobic oxidation of methane at a highly dynamic bubbling site in the Eastern Sea of Marmara (Çinarcik Basin). Deep Sea Research Part II: Topical Studies in Oceanography.

Tryon, M.D., Henry, P., Cagatay, M.N., Zitter, T.A.C., Geli, L., Gasperini, L., Burnard, P., Bourlange, S., Grall, C., 2010. Pore fluid chemistry of the North Anatolian Fault Zone in the Sea of Marmara: A diversity of sources and processes. Geochemistry Geophysics Geosystems 11.

Tryon, M.D., Henry, P., Hilton, D.R., 2012. Quantifying submarine fluid seep activity along the North Anatolian Fault Zone in the Sea of Marmara. Marine Geology 315, 15-28.

Yang, H., Lu, H., Ruffine, L., 2018. Geochemical characteristics of iron in sediments from the Sea of Marmara. Deep Sea Research Part II: Topical Studies in Oceanography.

Zitter, T., Henry, P., Aloisi, G., Delaygue, G., Çagatay, M., Mercier de Lepinay, B., Al-Samir, M., Fornacciari, F., Tesmer, M., Pekdeger, A., 2008. Cold seeps along the main Marmara fault in the Sea of Marmara (Turkey). Deep-Sea Research Part I 55, 552-570. 